ISSN 2179-345X

Licenciado sob uma Licença Creative Commons

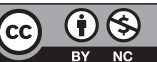

BY NC

\title{
Tutela ambiental e audiência judicial: pressupostos democráticos via contraditório
}

\author{
Environmental protections and judicial hearing: \\ democratic presuppositions through contradictory
}

\begin{abstract}
Márcio Ricardo Staffen ${ }^{[a]}$, Zenildo Bodnar ${ }^{[b]}$
[a] Mestrando em Ciência Jurídica pela Universidade do Vale do Itajaí, na linha de pesquisa Principiologia, Constitucionalismo e Produção do Direito, Graduado em Direito pela Universidade do Vale do Itajaí, bolsista Capes, advogado (OAB/SC), Balneário Piçarras, SC - Brasil, e-mail: staffen_sc@yahoo.com.br

[b] Pós-Doutor em Direito Ambiental pela Universidade Federal de Santa Catarina e Pós-Doutor em Direito Ambiental pela Universidad de Alicante (Espanha), Doutor em Direito pela Universidade Federal de Santa Catarina (UFSC), Mestre em Ciência Jurídica pela Universidade do Vale do Itajaí (Univali), Graduado em Direito pela Universidade Estadual de Ponta Grossa (UEPG), professor nos programas de Doutorado e Mestrado em Ciência Jurídica da Universidade do Vale do Itajaí, Pesquisador CNPq, juiz federal, Balneário Camboriú, SC - Brasil, e-mail: zenildo@univali.br
\end{abstract}

\section{Resumo}

O presente artigo analisa a importância da democratização do processo judicial ambiental como forma de concretização do direito e dever fundamental de proteção do meio ambiente pelo Poder Judiciário. Com a utilização do método indutivo, o presente trabalho destaca a insuficiência da dogmática processual clássica para a resolução dos conflitos 
ambientais. Defende-se a necessidade da consolidação de um novo paradigma de prestação jurisdicional que assegure e facilite a participação direta do cidadão no tratamento dos conflitos ambientais, com especial ênfase à audiência judicial participativa. Sob essa óptica, apresenta-se a confluência da noção de processo como procedimento em contraditório realizado em simetria de armas.

Palavras-chave: Audiência judicial participativa. Acesso à justiça ambiental. Contraditório.

\section{Abstract}

This article examines the importance of democratization of the judicial process environment as a way of achieving the basic right and duty to protect the environment by the judiciary. Using the method inductive, this study highlights the inadequacy of the classical dogmatic procedure for the resolution of environmental conflicts. It supports the need for consolidation of a new paradigm of adjudication to ensure and facilitate the direct participation of citizens in the treatment of environmental conflicts, with special attention to the court hearing participatory. From this perspective shows the confluence of the notion of process as adversarial procedure performed in the symmetry of arms.

Keywords: Participatory judicial hearing. Access to environmental justice. Contradictory.

\section{Introdução}

O Poder Judiciário desempenha um papel cada vez mais relevante na concretização dos Direitos Fundamentais em busca de um meio ambiente saudável e equilibrado. Esse papel deve ser desempenhado com idealismo, criatividade e responsabilidade social, nos ditames do Estado Democrático de Direito.

A sociedade contemporânea da globalização, da revolução tecnológica e de ataques suicidas do homem ao meio ambiente caracteriza um novo tempo (STAFFEN; BODNAR, 2010). Esse tempo é de grandes mudanças e transformações, que atingem espaços jurídicos, políticos, 
econômicos e até culturais. Surgem, então, novos direitos, novos atores sociais e novas demandas, as quais reclamam novas e inteligentes formas de equacionamento.

Essa nova realidade impõe grandes desafios ao Poder Judiciário e exige de seus integrantes novas formas de prestação jurisdicional, mais democráticas, eficazes socialmente e comprometidas com os reais anseios da comunidade (PÉREZ LUÑO, 2003). Essas novas formas precisam transcender a ideia de processo como direito subjetivo e avançar além da visão instrumental (DINAMARCO, 2005), presa às questões individuais, típicas do paradigma liberal-normativista, que, de alguma maneira, expõe a realidade surreal de Franz Kafka.

Neste artigo, defende-se a necessidade de uma nova dogmática processual para a tutela do meio ambiente. Respostas jurisdicionais mais efetivas necessitam de uma nova construção processual, capaz de resolver os problemas da atualidade. Pois, como é de notório conhecimento, as questões do século XXI são debatidas, ainda a partir da lógica jurídica do século XVIII, derivada imediata das glosas medievais. Sem demora, faz-se imperioso olhar o novo com a visão renovada.

Propõe-se a consolidação de uma nova cultura na prestação jurisdicional para a proteção do direito fundamental ao meio ambiente sadio e equilibrado. Essa cultura efetivamente contribuiria para a emancipação do homem na sociedade, dotada de sensibilidade moderna, com uma perspectiva mais humana, que efetivamente transformaria o foro judicial em um espaço ampliado de cidadania substancialmente democrática (MIGLINO, 2010, p. 57). Com urgência, na vigência do Estado Democrático de Direito, é preciso resgatar o devido processo legal material e, necessariamente, o princípio do contraditório na óptica de Elio Fazzalari ${ }^{1}$.

1 Elio Fazzalari (1925-2010) exerceu a docência na Universidade de Perugia, na de Pisa e na de Roma "La Sapienza", da qual é Professor Emérito de Direito Processual Civil. Foi presidente da Associação Italiana de Estudiosos de Processo Civil. Entre suas principais obras estão Istituzioni di diritto procesuale e Lezioni di diritto procesuale. 


\section{O papel do Poder Judiciário na concretização das normas ambientais}

A Constituição da República Federativa do Brasil de 1988 (BRASIL, 1988) impõe ao Estado e à sociedade o dever de preservar e proteger o meio ambiente em todos os lugares e os tempos para todas as gerações vindouras (CRFB/1988, art. 225). O Poder Judiciário como um dos Poderes do Estado tem a função proeminente de fazer valer esse comando constitucional e também o dever fundamental de proteger o meio ambiente.

A função promocional do direito presente nas decisões do Poder Judiciário merece especial realce em matéria ambiental, tendo em vista a natureza pedagógica das decisões que devem promover uma nova cultura ecológica conservacionista, estimulando ações concretas em prol do meio ambiente saudável. Destaca Freitas (1998, p. 29-30) que o juiz possui papel relevante por exercer um dos poderes da República "em nome do povo e ter por obrigação defender e preservar o meio ambiente para presentes e futuras gerações" (arts. $1^{\circ}$, parágrafo único e 225, caput) e também como intérprete das normas ambientais.

Os problemas do direito do ambiente são altamente complexos e cada vez mais rodeados de incertezas e novos desafios. As fórmulas generalistas estabelecidas pelo Estado por meio de seus legisladores para o meio ambiente nem sempre são adequadas para a solução da infinita quantidade de casos e situações existentes, especialmente considerando o conceito aberto e relativo do próprio meio ambiente.

A dogmática processual tradicional, construída apenas para resolver conflitos individuais, também não equaciona com eficácia as ofensas aos bens ambientais. Por isso, deve o Estado constitucional ecológico facilitar o acesso do cidadão à justiça ambiental, não apenas criando novos instrumentos de defesa, mas principalmente conferindo uma interpretação adequada aos instrumentos processuais já existentes, como da Ação Civil Pública e da Ação Popular, para conferir-lhes a verdadeira amplitude e potencialidade. Dentro desse contexto, o papel do Poder Judiciário é ainda mais importante na concretização do direito fundamental, do meio 
ambiente saudável e do dever fundamental de todos de protegê-lo para a construção desse verdadeiro Estado constitucional ecológico.

As tensões entre o homem e a natureza formam uma constante na história da humanidade. A busca irresponsável do progresso tem levado o homem a ser o inimigo número um da natureza na medida em que é o maior protagonista de condutas ofensivas ao ambiente. Assim, o compromisso de todos e em especial do Poder Judiciário é contribuir para a mudança desse paradigma individualista, desenvolvendo uma nova ética mais solidária, responsável e comprometida com o meio ambiente, patrimônio maior de toda a humanidade.

Para alcançar esse desiderato, a jurisdição deverá focar a análise na ideia de dever fundamental ${ }^{2}$, pois o meio ambiente, antes de ser um direito intergeracional, é um dever fundamental ${ }^{3}$ que impõe uma conduta ativa de todos os membros da sociedade organizada, em especial dos poderes públicos. A construção de uma nova hermenêutica focada na ideia de dever fundamental certamente representará um ganho de efetividade, pois é muito mais importante identificar os responsáveis pelo descumprimento do desse dever do que os titulares de eventual direito subjetivo.

$\mathrm{Na}$ jurisdição focada na ideia de dever fundamental, merece destaque o papel do magistrado, em especial a sua sensibilidade humana. Isso se justifica pela necessidade de a decisão ter a cara do juiz, de seu pensamento responsável e de seu sentimento de justiça afinado com os reais anseios da sociedade a que serve. Os juízes, como peças-chave para o engrandecimento da democracia, devem protagonizar em cada ato a transformação da sociedade, cada vez mais plural e diversificada no novo

2 Os deveres fundamentais são as exigências constitucionais imprescindíveis para o alcance dos objetivos republicanos (Art. 3, CRFB/88). Além do dever fundamental de proteção ao ambiente, também são exemplos de deveres fundamentais: solidariedade, pagamento de tributos, respeito à função social da propriedade, cooperação no processo, dentre outros.

3 Sobre o tema dos deveres fundamentais é importante mencionada a obra de José Casalta Nabais (2004, p. 39-40) na qual este autor ressalta que; "os deveres fundamentais constituem uma categoria constitucional própria, expressão imediata ou directa de valores e interesses comunitários diferentes e contrapostos aos valores e interesses individuais consubstanciados na figura dos direitos fundamentais." 
milênio. O magistrado idealista precisa acreditar que pode mudar o mundo para melhor, banindo dele a ética egoísta e disseminando uma ética solidária e ambientalmente correta.

O escopo social e político do processo ambiental exige a adoção de procedimentos mais flexíveis e democráticos, que possibilitem a participação mais efetiva das partes e de todos os interessados, mormente em questões que envolvam expressivo número de pessoas e interesses colidentes. É o que ocorre nas lides ambientais, pois, nesses casos, a demanda não interessa apenas às partes formalmente constituídas e representadas na relação processual, mas interessa a toda sociedade.

A sociedade atual da revolução tecnológica e da intensificação do fenômeno da globalização é muito mais desafiadora para os juízes. Esse quadro demonstra a grande responsabilidade que tem a magistratura para a construção de um mundo melhor, mais humano e igualitário e com mais oportunidades para todos.

O juiz cidadão, comprometido com os novos reclamos da sociedade contemporânea, deve buscar, no cotidiano de sua atuação, ampliar os mecanismos de acesso ao pleno desenvolvimento humano, conferindo especial proteção aos Direitos Fundamentais (sociais e individuais), previstos pela nossa Constituição explícita ou implicitamente (meio ambiente, alimento/salário, moradia, educação, saúde, emprego e outros).

Pajardi (1989) defende que devemos criar um novo operador do direito, menos técnico e que saiba superar, integrar e completar a técnica com sensibilidade social e abundância de humanidade. A importância da sensibilidade social do julgador também é destacada por Faria (1992), o qual é enfático ao afirmar que, na resolução de conflitos sociais, o juiz deve atuar como um 'arquiteto social', modificando as concepções discriminatórias da ordem jurídica vigente, valendo-se de suas sentenças como instrumentos, que auxiliem os grupos e as classes subalternas a se constituírem efetivamente como "sujeitos coletivos de direito".

É concretizando os Direitos Fundamentais e em especial o direito de todos ao meio ambiente protegido que o magistrado estará legitimando a sua atuação diante da sociedade. Ibañez (2002, p. 381) é 
enfático ao concluir que a legitimidade original do juiz deve completar-se necessariamente "mediante o exercício do poder judicial numa autêntica qualidade constitucional, pela sua funcionalidade efetiva de garantia dos direitos fundamentais".

Como pacificador social, deve o magistrado incentivar com responsabilidade a conciliação, valorizando fórmulas e critérios eleitos pelos próprios litigantes para colocar fim ao litígio, ainda que tenha que utilizar procedimentos não previstos pelo legislador processual, como audiências públicas, com a participação de representantes de associações, autoridades públicas, entre outros, ainda que não estejam formalmente incluídos na relação processual.

\section{Necessidade de uma nova dogmática processual para a tutela do ambiente}

A configuração dos novos direitos a sua ordem de conflituosidade que comportam e a diversidade de configuração exigem uma nova dogmática processual para sua adequada tutela. Não é possível solucionar de maneira eficaz os conflitos envolvendo interesses difusos e coletivos com os instrumentos jurídicos construídos para a tutela judicial dos direitos interindividuais.

Para a maioria da doutrina, a ação é ainda entendida como sendo um direito subjetivo, ou seja, direito de cada um. Seu exercício válido requer que seja demonstrado já no início de forma instrumental e provisória que a pretensão é objetiva e subjetivamente razoável (possibilidade jurídica do pedido), e quem pede é o provável titular da relação jurídica de direito material (legitimidade).

As ações constitucionais utilizadas na proteção do meio ambiente perdem a sua efetividade em função da teimosia dos operadores do direito em aplicar as concepções clássicas do processo tradicional às lides coletivas. Esse fato empobrece a sua eficácia e diminui a potencialidade desses importantes instrumentos de tutela dos novos direitos. 
Os direitos difusos exigem uma revisão acerca de institutos como: legitimidade, verdade real, contraditório, coisa julgada, adstrição ou congruência, inércia, entre outros dogmas do processo tradicional arquitetado para a solução dos conflitos individuais. A legitimidade tanto ativa como passiva deve ser vista numa perspectiva ampliada. A coisa julgada deve ter efeitos erga omnes. O juiz deve julgar além do pedido quando outras medidas forem necessárias para a plena proteção do meio ambiente e não pode ser um mero expectador inerte do desenrolar do processo; deve, antes, assumir uma postura ativa na busca da verdade suficiente e da plena realização da justiça.

$\mathrm{Na}$ tutela ambiental, não precisa o juiz buscar a verdade material, tendo em vista que esta é por demais utópica e inatingível. Ele deverá lutar por uma verdade ideal, suficiente, especialmente em sede de cognição sumária quando é instado a prestar a tutela de urgência. As inevitáveis crises de incertezas na avaliação da prova devem sempre colocar o risco do lado oposto ao meio ambiente (LUHMANN, 1980).

O contraditório como garantia constitucional substancial não pode ser entendido como um singelo direito de informação e de reação da parte formalmente habilitada no processo. O contraditório não é apenas a faculdade de dizer e de contradizer, mas sim a oportunidade concreta de participação das partes intervenientes na construção ativa do provimento jurisdicional final, como se verá na sequência. O provimento jurisdicional será produzido com a efetiva cooperação de todos e não será um ato de capricho ou autoritarismo do magistrado.

A superação dos obstáculos à efetividade das ações constitucionais depende da mudança da mentalidade dos operadores do direito. Os institutos processuais devem sempre ser entendidos/interpretados à luz da Constituição Federal, e o acesso à justiça como princípio básico do Estado Democrático de Direito deve ser compreendido numa noção bem mais ampla que a singela preocupação com custas judiciais.

A utilização adequada e eficaz das ações constitucionais, com a superação dos conceitos e dogmas da processualística clássica, antes até de grandes reformas legislativas, depende principalmente da 
conscientização dos operadores jurídicos (BRANDÃO, 2001) para que o tão almejado acesso à justiça seja um ideal ao alcance de todos os cidadãos.

Importa reconhecer, em linhas gerais, que no panorama que se desnuda já não basta advogar por um circuito clássico procedimentalista, adstrito ao modelo liberal. É preciso reconhecer o Poder Judiciário como instituição basilar nas democracias hodiernas, não limitado às funções meramente declaratórias. O Judiciário, o Ministério Público e demais instituições envolvidas na prática jurídica necessitam reger um efetivo sistema de freios e contrapesos interessado na participação dos destinatários do ato decisório, a partir de um ambiente democraticamente substancial que substitua a ideia de que a decisão judicial é uma mera aplicação lógico-aritmética.

A prestação jurisdicional também possui um caráter pedagógico, pois deve servir como forma de educação, confirmando-se, assim, a conclusão de Nalini (1998, p. 11) quanto ao papel do juiz na conscientização ecológica segundo o qual "o julgamento contém, subsidiariamente à solução da controvérsia à solução da controvérsia, um ensinamento”.

\section{Princípio da participação e o acesso à justiça ambiental}

Um dos princípios ambientais mais importantes é o da participação segundo o qual os cidadãos devem participar dos procedimentos e das decisões ambientais, não apenas por serem os destinatários diretos destas, mas também pelo compromisso que todos devem ter para com a defesa e a proteção do meio ambiente. A participação de todos na proteção dos bens ambientais é salutar para o desenvolvimento de uma ética ambiental comprometida com um modo de vida ambientalmente correto e afinado com os princípios da ecologia, os quais religam o homem com a teia da vida (BOFF, 2000).

O princípio da participação conforme Fiorillo (2003) é o agir em conjunto que contempla dois elementos fundamentais: a informação e $a$ 
educação. A participação é relevante para que o cidadão seja informado acerca de suas responsabilidades para com o meio ambiente.

A participação dos cidadãos nos procedimentos é fundamental para que tenham a plena conviç̧ão de que, no processo, tudo acontece pelo esforço sério, justo e intenso na investigação da verdade e na busca da justiça para haver certeza de que a ajuda das instituições, em especial do Poder Judiciário, repercutirá positivamente na proteção dos seus direitos (LUHMANN, 1980).

A importância da participação nas ações judiciais como forma de acesso à justiça é destacada por Machado (2000), que, após apontar como fundamentos para a participação a Convenção de Aarhus (Art. $9^{\circ}$. § §1-5) e a Declaração do Rio de Janeiro de 1992, enfatiza que: “a possibilidade de as pessoas e de as associações agirem perante o Poder Judiciário é um dos pilares do Direito Ambiental" (MACHADO, 2000, p. 77).

A participação no procedimento, para Luhmann (1980, p. 9697), tem um valor especial na cooperação de todos, fato que serve para a compreensão das "premissas obrigatórias de comportamento e de compromisso pessoal". O devido processo legal substancial aplicado ao meio ambiente deve ser construído a partir da concretização dos direitos e das garantias fundamentais e da participação dos cidadãos nos procedimentos administrativos e judiciais.

A participação é o ponto de partida para a proteção efetiva do meio ambiente. Ninguém vai salvar o planeta sozinho, pois somente o engajamento de todos na gestão dos recursos naturais e do potencial ecológico do planeta garantirá um projeto civilizatório mais promissor para o futuro da humanidade.

A construção da decisão em matéria ambiental não pode prescindir da efetiva participação, especialmente considerando as suas necessárias imbricações dos fatores econômicos, políticos e sociais. A interação desses fatores potencializa o interesse da população na construção das decisões, quer seja no plano legislativo, administrativo ou judicial. 
O Estado não pode abrir mão da parceria efetiva da sociedade civil na tutela do ambiente, pois foi exatamente da tomada da consciência coletiva da crise ecológica do planeta que surgiu o Direito Ambiental. Para que os cidadãos reconheçam a importância das normas e das decisões ambientais, é de fundamental importância que participem da sua construção, pois, como principais destinatários delas, precisam antes de tudo de informação e de tomada da consciência. Nesse cenário, as figuras petrificadas ganham vida, de sorte que o direito e o ideal de justiça transcendem o caráter de ficção para invadir a realidade.

$\mathrm{Na}$ atual sociedade de riscos incertos, globais e futuros, é fundamental a participação de todos os atores na tomada de decisão. Essa necessidade é destacada por Leite e Ayala (2004, p. 121), segundo os quais a composição de interesses e ponderações completas somente serão possíveis "mediante processos bem informados, que garantam participação pública e democrática no momento da seleção das escolhas adequadas", especialmente porque a ciência não fornece respostas corretas e conclusivas acerca das complexas questões da atual sociedade do risco, sendo imprescindível uma abordagem transdisciplinar. Isso tudo ocorre porque a gestão ambiental democrática, além de imprescindível, é "um convite à ação dos cidadãos para participar na produção de suas condições de existência e em seus projetos de vida" (LEFF, 2005, p. 57).

\section{Audiência judicial participativa}

A possibilidade de convocação de audiências públicas, para a discussão de importantes temas de interesse coletivo, passou a ganhar especial atenção do legislador a partir da Constituição de 1988. O artigo 58, parágrafo $2^{\circ}$, inciso II, prevê a possibilidade de convocação de audiências públicas pelas comissões legislativas, com entidades da sociedade civil e com especialistas em determinadas matérias. A Lei Orgânica da Saúde (8.080/90) e a Lei de Assistência Social (8.742/93) também disciplinam a possibilidade de audiências e conferências públicas. 
O Direito Ambiental Brasileiro, seguindo uma tendência mundial $l^{4}$, assegura ao cidadão a possibilidade de participar da política ambiental, nas diversas esferas de poder do Estado: a) Legislativo: no processo de criação do Direito Ambiental por meio de iniciativa popular, referendo e plebiscito; b) Executivo: composição de órgãos colegiados, a exemplo do Conama, e a participação em audiências públicas realizadas na execução dos Estudos de Impactos Ambientais e na apresentação dos respectivos relatórios (nos casos de impacto ambiental mais significativo, conforme resoluções de n. 001/86 e 009/87 do Conama); c) Judiciário: legitimidade para propor: ação popular, mandado de segurança e mandado de injunção.

Apesar dessas possibilidades, formalmente garantidas ao cidadão, o que se observa na prática é um grave déficit democrático, especialmente no que se refere ao acesso à justiça. Não há notícia de participação popular no processo de criação do Direito Ambiental no Brasil, pois os raríssimos casos em que ocorreu a iniciativa popular, plebiscito e referendo trataram de outros temas. A participação do cidadão nas audiências públicas realizadas na fase do licenciamento, apesar de constituir um importante avanço está estratégia de legitimação, ainda não vem sendo utilizada adequadamente. Isso ocorre especialmente pela falta de conscientização da população, pela falta de oportunidade de manifestação qualificada para o público em geral e até em função dos locais e horários em que essas audiências são realizadas.

O que é mais relevante destacar, considerando os objetivos específicos deste artigo, é a carência de legitimação democrática para a gestão e a implementação das políticas públicas e das decisões em matéria ambiental no âmbito da jurisdição.

No Direito Brasileiro, o cidadão, apesar de ser o maior interessado na tutela do ideal meio ambiente, foi praticamente esquecido pelo legislador, que somente reservou algumas hipóteses restritas que

4 A participação no processo de licenciamento é assegurada como estratégia democrática de implementação ambiental nos seguintes países: Canadá, França, Suíça, Noruega, Itália, Grécia e é recomendada por diretiva para todos os países da União Europeia. 
possibilitam a sua intervenção. A Lei da Ação Civil Pública, apesar da inclusão recente da Defensoria Pública como legitimada, ainda exclui, numa opção infeliz e autoritária, a participação ativa do cidadão da tutela do meio ambiente ao negar ao maior advogado do meio ambiente o poder de ação, que é uma forma de exercício substancial de democracia. No caso da Ação Popular, a participação do cidadão na tutela do meio ambiente, mesmo após o advento da Constituição de 1988, ainda é restrita aos casos em que há participação do Poder Público, pois exige que atos ou omissões deste sejam impugnados.

Nesse contexto, é fundamental que o cidadão tenha oportunidade de participar, como sujeito ativo e protagonista das decisões ambientais, por intermédio das audiências públicas judiciais, contribuindo com o tratamento adequado das lides ambientais. A convocação de audiências públicas no processo judicial deverá ocorrer em todos os casos em que a participação popular seja relevante em razão do alto grau de litigiosidade e da quantidade de Direitos Fundamentais envolvidos e em rota de colisão. Isso deve ocorrer, por exemplo, nos caos de ocupações irregulares de áreas de Preservação Permanente, criações de parques, entre outros.

A democratização do acesso à justiça ambiental, com ampla participação popular, por intermédio de audiências públicas judiciais, é a melhor forma de legitimar a atuação do Poder Judiciário na tutela do ambiente e também serve como mecanismo estratégico de conscientização e educação ambiental. É com a cooperação de todos e com a inteligência coletiva que será possível assegurar a proteção efetiva dos interesses e dos Direitos Fundamentais envolvidos direta ou indiretamente nos litígios ambientais, em especial a garantia plena da higidez ambiental para uma melhora contínua das condições de existência humana no planeta.

Acerca desse prisma, aproximando Psicologia e Direito, parece relevante no estágio em que se vive concordar que o Direito caminha rumo uma "zona de conforto" 5 e prevenção de danos, prejuízos e vítimas. Há nisso uma confluência de interesses com o modo de jurisdicionar em sede de

\footnotetext{
5 Sugere-se: MELMAN (2008).
} 
audiência judicial participativa, em que os participantes propõem uma resposta legal a todas as principais causas de conflito suscitadas pela alteridade, pela desigualdade ou pela relação de foraclusão do terceiro via contraditório.

\section{O processo como procedimento em contraditório}

Ao longo dos períodos históricos, os bens socialmente considerados de maior relevância foram incorporados em documentos escritos que buscaram estabelecer limites ao Estado, declarando direitos e assegurando medidas garantidoras das disposições declaratórias. Perante novas ameaças, a ciência jurídica deve adotar novos posicionamentos no intuito de estabelecer ou preservar o ordenamento jurídico de um desmantelamento que afetará diretamente a ordem social. Para tal afirmação, a história é rica em exemplos: Magna Charta, Bill of Rigths, Declaração Universal dos Direitos do Homem e do Cidadão, direitos sociais e, recentemente, direitos relativos ao meio ambiente, biodireitos, etc.

Nessa linha de raciocínio, os direitos acerca do meio ambiente reclamam, como direitos difusos, uma nova caracterização para a teoria do processo. Tal renovação impõe uma compreensão própria que substitua a ideia de que o rito se fazia pelo rito e a forma se cumpria pela forma. A ciência processual não é só a ciência das petições, das provas, dos recursos, das execuções, das orientações jurisprudenciais, das formas, dos prazos (GONÇALVES, 2001).

De igual forma, na vigência do Estado Democrático de Direito, fixar o conceito de processo como relação jurídica, na questão do direito subjetivo ou na teoria da situação jurídica, reproduz o problema do direito subjetivo como poder de exigir a conduta de outrem. A prática do processo como relação jurídica corrobora na noção de ascendência do sujeito ativo sobre o sujeito passivo (FAZZALARI, 2006), uma vez que este é obrigado a satisfazer a vontade daquele, não importando as razões da celeuma.

Por sua vez, a teoria da situação jurídica dá um passo avante quando substitui a máxima da relação jurídica sustentada no direito 
subjetivo pela disciplina da lei que regula as faculdades, os poderes e os deveres. Isso, porém, é pouco. Apenas tira o processo da ideia de individualismo para centrá-lo num espaço normativo, ambos típicos do paradigma de Estado Liberal alicerçado no dogma da autonomia da vontade.

Por tudo o que já foi adiantado alhures, Elio Fazzalari apresenta uma senda hábil ao escopo democrático-participativo do processo. Ao estabelecer com primazia a noção de processo como procedimento em contraditório e fazer do contraditório o elemento distintivo de processo e procedimento, Fazzalari afastou o retrógado clichê da relação jurídica processual que sustenta a instrumentalidade do processo, capitaneada no Brasil por Dinamarco e alicerçada em Leibmann e Chiovenda, incapaz, nesse momento, de dar respostas efetivas aos problemas sociais.

Nesse quadro, a proposta do processo como procedimento em contraditório traduz o ápice do pensamento jurídico na condução efetivamente dialética e democrática do processo. É justamente o contraditório que distingue o processo do procedimento:

a referência à estrutura dialética como a ratio distinguendi permite superar anteriores tentativas de definir o "processo", como aquele conceito segundo o qual existe processo onde exista, em ato ou em potência, um conflito de interesses, e aquele segundo o qual existe processo toda vez que participe da formação do ato um sujeito portador de um interesse distinto daquele interesse do autor do ato nos quais os interesses e as suas possíveis combinações são dados metajurídicos (FAZZALARI, 2006, p. 120).

Para identificar, portanto, o processo, é fundamental a participação dos destinatários da decisão em contraditório paritário. Isso não significa a mera participação dos sujeitos do processo; não é o dizer e o contradizer; não se resume em discussão. De igual forma, o contraditório não se exaure com a mera oitiva da parte, cuja máxima ainda impera na noção de audiatur [...] et altera pars (visão instrumental). Para Gonçalves (2001, p. 127), o “contraditório é a igualdade de oportunidade no processo, é a igual oportunidade de igual tratamento, que se funda na liberdade de todos perante a lei”, como 
já havia registrado von Jhering (1956), para quem a igualdade jurídica propiciada pelo contraditório é condição de justiça no processo.

Acrescente-se que a exteriorização do princípio do contraditório, na proposta de Fazzalari, opera-se em dois momentos, conforme atesta Rosa (2006). Inicialmente com a informazione, consistente no dever de informação para que possam ser exercidas as posições jurídicas perante as normas processuais e, em seguida, a reazione, revelada pela possibilidade de movimento processual, sem se constituir, todavia, em obrigação.

Desse argumento brota a noção de contraditório em simétrica paridade, que vincula compulsoriamente o autor, o réu, o interveniente, o juiz, o representante do Ministério Público (quando necessário) e seus auxiliares a atuarem em pé de igualdade. Aqui novamente visualiza-se um contraponto à noção instrumental do processo, pois garante a dialética participação não só de autor e réu, tradicionais destinatários do ato, mas também das demais pessoas envolvidas na atividade jurisdicional. Sob esse enfoque, todos são partes, como bem observa Pellegrini (2003).

Contudo, as lições de Fazzalari (2006) não se encerram na noção de processo como procedimento em contraditório. Traz a baila o conceito de norma como um cânone de valoração de uma conduta, entendida como alguma coisa de aprovável, de preferível em determinada cultura. Assim, a exposição desse panorama permite afastar a nefasta proposta de Kelsen, que concentrou o estudo da juridicidade no ilícito e para quem o processo traduz um ilícito (GONÇALVES, 2001). Para Fazzalari, portanto, o processo deve ser compreendido e praticado como uma garantia; logo, quando se inicia um processo, não se exercita um ilícito; ao reverso, pratica-se um direito constitucionalmente assegurado.

Embora já consignado, ainda vivencia-se um momento de solução de conflitos orientado pela matriz individual-liberal-normativista suportada pelo primado da autorregulação. Todavia, como nos instrui Nunes (2006), a noção de legitimidade está vinculada aos procedimentos que possibilitam a participação igualitária e efetiva do indivíduo na construção do provimento, sendo que a legitimidade do direito "se dá pela empreitada cooperativa, que se apresenta por meio de procedimentos que 
possibilitam a participação igualitária e efetiva de todos os interessados no processo de produção das leis, bem como no processo de aplicação das normas" (NUNES, 2006, p. 52).

Nesse quadro renovado, a Constituição passa a ser a pedra angular para a edificação de um sistema decisório democrático cultivado dialeticamente, que necessita ser compreendida, essencialmente, como a estruturação de um sistema de Direitos Fundamentais que subsidia as condições procedimentais de institucionalização jurídica das formas de comunicação, nos dizeres de Oliveira (2001).

É exatamente nesse contexto comunicativo-processual-constitucional que o princípio do contraditório, na percepção de Fazzalari, ganha relevância, uma vez que defende um modelo substancial de participação, além de um simples procedimento. Por meio do princípio do contraditório é que se estabelece racionalmente uma relação comunicativa (argumentativa) entre os destinatários do provimento jurisdicional, tanto na esfera administrativa quanto na judicial. Recordando as aulas de Física, o princípio do contraditório necessita urgentemente ser praticado como uma força centrípeta que, por sua dinâmica, tem o condão de trazer todas as considerações para o núcleo do processo.

Como bem observa Habermas (2003), todo aquele que se envolve numa prática argumentativa tem que supor inicialmente que, em princípio, todos os possíveis afetados podem participar, na condição de livres e iguais, de uma "garimpagem cooperativa" em busca da verdade, na qual a coerção que se admite é a do melhor argumento, exclusivamente. Logo, o processo deixa de ser uma luta, cujo objetivo é erradicar o adversário, para assumir o caráter de um jogo, em que impera a racionalidade dos atores que buscam vencer pela maior "liquidez" de seus argumentos (STAFFEN; CADEMARTORI, 2010).

Pela perspectiva habermasiana, pode-se afirmar que todos os participantes do processo, quaisquer que sejam seus fundamentos, fornecem, via princípio do contraditório, contribuições ao discurso que, praticado em simétrica paridade, possibilita que a decisão final seja uma "fusão de horizontes", como quer Gadamer (2003). 
Não resta dúvida que, segundo Gonçalves (2001, p. 167):

[...] se lhes é garantido, pelo contraditório, a participação nos atos processuais que preparam o provimento, é uma consequência dessa garantia que as partes saibam por que um pedido foi negado ou por que uma condenação foi imposta. Elas viveram o processo, ou tiveram a garantia de vivê-lo, participaram do seu desenvolvimento, reconstruindo a situação de direito material sobre que deveria incidir o provimento e, nessa reconstrução, fizeram, juntamente com o juiz, o próprio processo, na expectativa do provimento final.

Por essa razão, a verdade das proposições ou a correção das normas depende, em última instância, de que se possa alcançar um consenso num ambiente de total liberdade e de simetria entre os envolvidos no diálogo discursivo-argumentativo (ATIENZA, 2003). Ademais, o Direito Ambiental como direito difuso requer, para a sua execução, o engajamento do maior número possível de indivíduos, haja vista o real interesse de todos. Para tanto, é preciso constituir espaços de cidadania e democracia para tal tarefa.

Ante o exposto, é evidente que o contraditório não se resume simplesmente em um princípio ou Direito Fundamental. Sua existência e sua satisfação substancial tipificam a materialização do Estado Democrático de Direito. Assim, para que este seja realmente produtivo, há de se dar um verdadeiro espaço ao contraditório, cabendo aos órgãos jurisdicionais velar pela real simetria e equilíbrio das posições cultivadas discursivamente (IBAÑEZ, 2005). Eis o papel das audiências judiciais participativas e a capacidade da proposta de Elio Fazzalari, que convidam todos isonômica e indistintamente para participarem dos processos decisivos.

\section{Conclusões articuladas}

O Poder Judiciário deve facilitar o acesso à justiça ambiental e a democratização do processo judicial com a utilização de procedimentos 
que assegurem a participação direta dos cidadãos nos procedimentos jurisdicionais em matéria ambiental.

A participação efetiva dos destinatários das normas ambientais é a melhor estratégia a ser utilizada para o tratamento das lides ambientais mais complexas, tendo em vista que concretiza também os princípios da: informação, educação, conscientização e comprometimento solidário com proteção do meio ambiente.

Para tanto, faz-se imperioso inaugurar uma nova concepção de teoria do processo, voltada para o caráter difuso do Direito Ambiental que, fundamentalmente, promova a garantia do processo como procedimento em contraditório. Deve ser um processo de inclusão dos indivíduos em um ambiente dialético, no qual se reconhece o mérito de tratar cada sujeito do direito como igual e idêntico.

A melhor forma de assegurar o princípio da participação no processo judicial é a realização de audiências judiciais participativas, nas quais deve ser oportunizada a participação direta dos cidadãos, de especialistas na matéria e das autoridades públicas, tudo para a construção conjunta da decisão social e ambientalmente mais justa e consequente.

Dessa forma, a discussão não se apresenta somente sobre o tipo de processo que se possui e as consequências da sua prática irrefletida, mas, sobretudo, impõe uma meditação sobre o tipo de Estado que se vislumbra.

\section{Referências}

ATIENZA, M. As razões do direito: teorias da argumentação jurídica. 3. ed. São Paulo: Landy, 2003.

BERI, M. et al. La magistratura nello Stato Democratico. Padova: Giuffrè, 1989.

BOFF, L. Ethos mundial: um consenso mínimo entre os humanos. Brasília: Letraviva, 2000. 
BRANDÃO, P. de T. Ações constitucionais: novos direitos e acesso à justiça. Florianópolis: Habitus, 2001.

DINAMARCO, C. R. A instrumentalidade do processo. 12. ed. São Paulo: Malheiros, 2005.

FARIA, J. E. Justiça e conflito: os juízes em face dos novos movimentos sociais. 2. ed. São Paulo: Revista dos Tribunais, 1992.

FAZZALARI, E. Instituições de direito processual. Campinas: Bookseller, 2006.

FIORILLO, C. A. P. Curso de direito ambiental brasileiro. 4. ed. São Paulo: Saraiva, 2003.

FREITAS, V. P. de. Direito ambiental em evolução. Curitiba: Juruá, 1998.

GADAMER, H.-G. Verdade e método I: traços fundamentais de uma hermenêutica filosófica. 5. ed. Petrópolis: Vozes, 2003.

GONÇALVES, A. P. Técnica processual e teoria do processo. Rio de Janeiro: Aide, 2001.

HABERMAS, J. Direito e moral (Tanner Lectures, 1986). In: HABERMAS, J. Direito e democracia: entre facticidade e validade. 2. ed. Rio de Janeiro: Tempo Brasileiro, 2003.

IBAÑEZ, P. A. Poder judicial e democracia política: lições de um século. Revista da AJURIS, Porto Alegre, n. 85, p. 381, mar. 2002.

IBAÑEZ, P. A. Garantismo: una teoría crítica de la jurisdicción. In: CARBONELL, M.; SALAZAR, P. (Org.). Garantismo: estudios sobre el pensamiento jurídico de Luigi Ferrajoli. Madrid: Trotta/Instituto de Investigaciones Jurídicas-UNAM, 2005.

LEFF, H. Saber ambiental: sustentabilidade, racionalidade, complexidade, poder. Petrópolis: Vozes, 2005. 
LEITE, J. R. M.; AYALA, P. de A. Transdisciplinaridade e a proteção jurídico-ambiental em sociedades do risco: direito, ciência e participação. In: LEITE, J. R. M.; BELLO FILHO, N. de B. (Org.). Direito ambiental contemporâneo. São Paulo: Manole, 2004. p. 99-125.

LUHMANN, N. Legitimação pelo procedimento. Brasília: UnB, 1980.

MACHADO, P. A. L. Direito ambiental brasileiro. 8. ed. São Paulo: Malheiros, 2000.

MELMAN, C. 0 homem sem gravidade: gozar a qualquer preço. Rio de Janeiro: Companhia de Freud, 2008.

MiglinO, A. La democrazia come diffusione del potere. Archivio Giuridico, Roma, v. 230, n. 1, p. 55-73, 2010.

NABAIS, J. C. 0 dever fundamental de pagar impostos: contributo para a compreensão constitucional do estado contemporâneo. Coimbra: Almedina, 2004.

NALINI, J. R. 0 futuro das profissões jurídicas. São Paulo: Oliveira Mendes, 1998.

NUNES, D. J. C. Direito constitucional ao recurso: da teoria geral dos recursos, das reformas processuais e da comparticipação das decisões. Rio de Janeiro: Lumen Juris, 2006.

OLIVEIRA, M. A. C. de. Direito processual constitucional. Belo Horizonte: Melhoramentos, 2001.

PAJARDI, P. Procedura civile: istituzioni e lineamenti generali. Milão: Giuffrè, 1989.

PELLEGRINI, F. de M. B. O processo, a jurisdição e a ação sob a ótica de Elio Fazzalari. Virtuajus, Belo Horizonte, v. 2, p. 5-7, 2003.

PÉREZ LUÑO, A. E. Derechos humanos, estado de derecho y constitución. 8. ed. Madrid: Tecnos, 2003. 
ROSA, A. M. da. Decisão penal: a bricolage de significantes. Rio de Janeiro: Lumen Juris, 2006.

STAFFEN, M. R.; CADEMARTORI, D. M. L. A função democrática do princípio do contraditório no âmbito do processo administrativo disciplinar: aproximações entre Elio Fazzalari e Jurgen Habermas. Revista Brasileira de Direitos Fundamentais \& Justiça, Porto Alegre, v. 4, n. 12, p. 235-246, 2010.

STAFFEN, M. R.; BODNAR, Z. A ética neoliberal e o princípio constitucional da eficiência administrativa: (im)possibilidade de flexibilização do direito fundamental ao meio ambiente. Revista Jurídica UNIGRAN, Dourados, v. 12, n. 23, p. 97-108, 2010.

VON JHERING, R. A evolução do direito. 2. ed. Salvador: Progresso, 1956.

Recebido: 22/07/2011

Received: 07/22/2011

Aprovado: 20/08/2011

Approved: 08/20/2011 